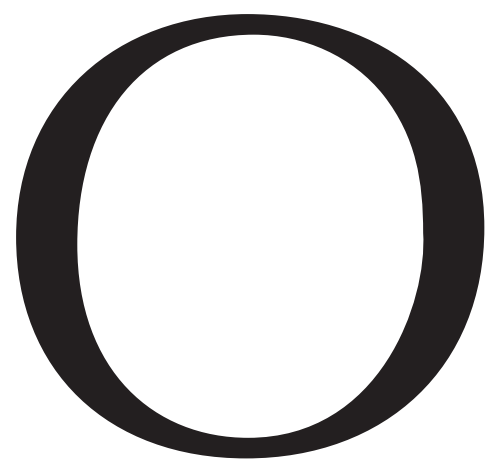

ALFRED CORDIVIOLA

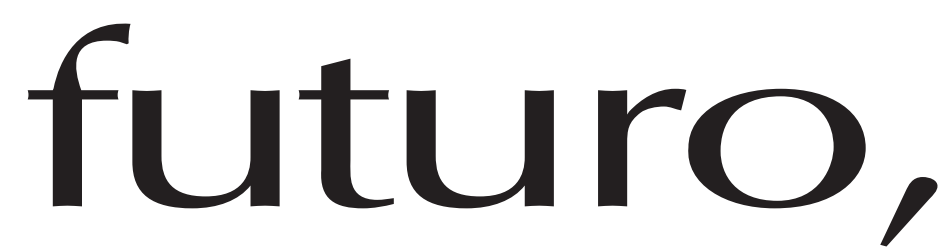
UMA LEITURA DA HISTÓRIA DO FUTURO

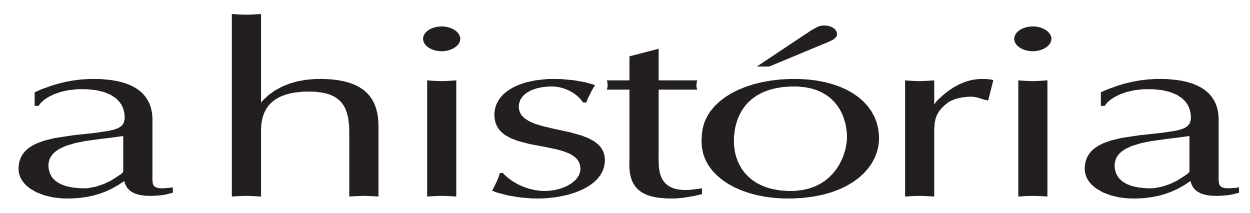

\section{O ESBOÇO E O SIMULACRO}

Dentro da profusa obra de Antônio Vieira, a História do Futuro ocupa um lugar singular. Na verdade, houve duas História do Futuro: uma, cogitada durante uma das viagens pela Amazônia, cujas primeiras linhas datam de 1649, senão de antes; outra escrita por Vieira às pressas, no cárcere da Inquisição, em 1664. Da primeira restaram apenas folhas avulsas, anotações, citações que poderiam eventualmente ser usadas. A segunda é a que se imprimiria com este título e que, no vasto plano do autor, era apenas o prolegômeno, a introdução do texto que anunciaria os destinos do mundo. Foi isso tudo o que ficou do que Vieira acreditava que seria sua obra mais grandiosa: um esboço, fragmentos e um simulacro.

Fragmentos: João Lúcio de Azevedo, um dos biógrafos do jesuíta (1), transcreve parte das páginas iniciais do que teria que ter sido propriamente a História do Futuro, escritas em 1649 ou antes. Essas folhas, como outras escritas já em Portugal a partir de 1664, seriam seqüestradas a Vieira pelo Santo Ofício dezesseis anos depois.

"Cap. 1. Começando a tratar do Quinto Império do Mundo (grande assunto deste nosso pequeno trabalho) para que procedamos com a distinção e clareza tão necessárias em toda a história, e muito mais neste gênero, a primeira cousa que se oferece para averiguar e saber é que impérios tenham sido ou hajam de ser os outros..."

O "nosso pequeno trabalho" deve ser entendido como tópico de modéstia antes que como expressão literal, pois sabe-se que só a primeira parte da obra, segundo as meditações do autor, prometia mais de sessenta capítulos, e que, mesmo assim, "não era ainda o livro, senão preparação ou aparato" (2) da História propriamente dita. Dessa primeira parte, só sete capítulos foram concluídos; ao plano de Vieira - plano que até um deus acharia estar fora das suas possibilidades - opuseram-se vários obstáculos: a própria extensão do trabalho, as constantes crises de saúde, e os vinte e seis meses durante os quais a Inquisição o apartou do mundo. E especialmente o tempo, obstáculo que, passando, derrubaria as principais hipóteses da História.

Algumas daquelas páginas seriam entregues por Vieira perante o Conselho do Santo Ofício em ocasião de seu julgamento: "Trinta cadernos de folha de papel escritos, alguns de sua letra. Estes cadernos não eram acabados de escrever, senão somente principiados" segundo 


\section{DO PADRE ANTÔNIO VIEIRA}

consigna o auto da sessão; incluíam capítulos da História, a justificativa das Esperanças de Portugal e notas avulsas (3). Esse material obrigaria Vieira a escrever as duas Representações (4), apologia que oréu apresentou a modo de defesa escrita entre 1665 e 1666.

$\mathrm{Na}$ História, Vieira pretendia demonstrar a validade das profecias de Bandarra, o sapateiro de Trancoso, autor das Trovas (1540). Esta composição anunciava a aclamação de D. João IV e a chegada do Quinto Império que - quando Portugal reconquistasse a Terra Santa - haveria de inaugurar os mil anos do reinado de Cristo; depois chegaria o AntiCristo, soltar-se-ia o diabo e viria por fim o dia do Juízo. O encarregado de consumar o reino de Cristo na terra, convertidos todos os infiéis e estabelecida a paz geral, seria um rei encoberto, e 1666 o ano em que haveria de começar o Quinto Império. D. João IV tinha morrido em 1657; conseqüentemente, deveria ressuscitar para obrar o que Bandarra profetizara. Por isso 1666, ano fatal prognosticado pelas Trovas e pelo próprio Apocalipse (666 é o número da Besta), era o prazo fixado pelas profecias, contra o qual a História do Futuro devia se debater, se queria ser aviso do porvir em vez de mera constatação do já acontecido. Para Vieira, 1666 marcava o limite de todas as especulações, e a data na qual

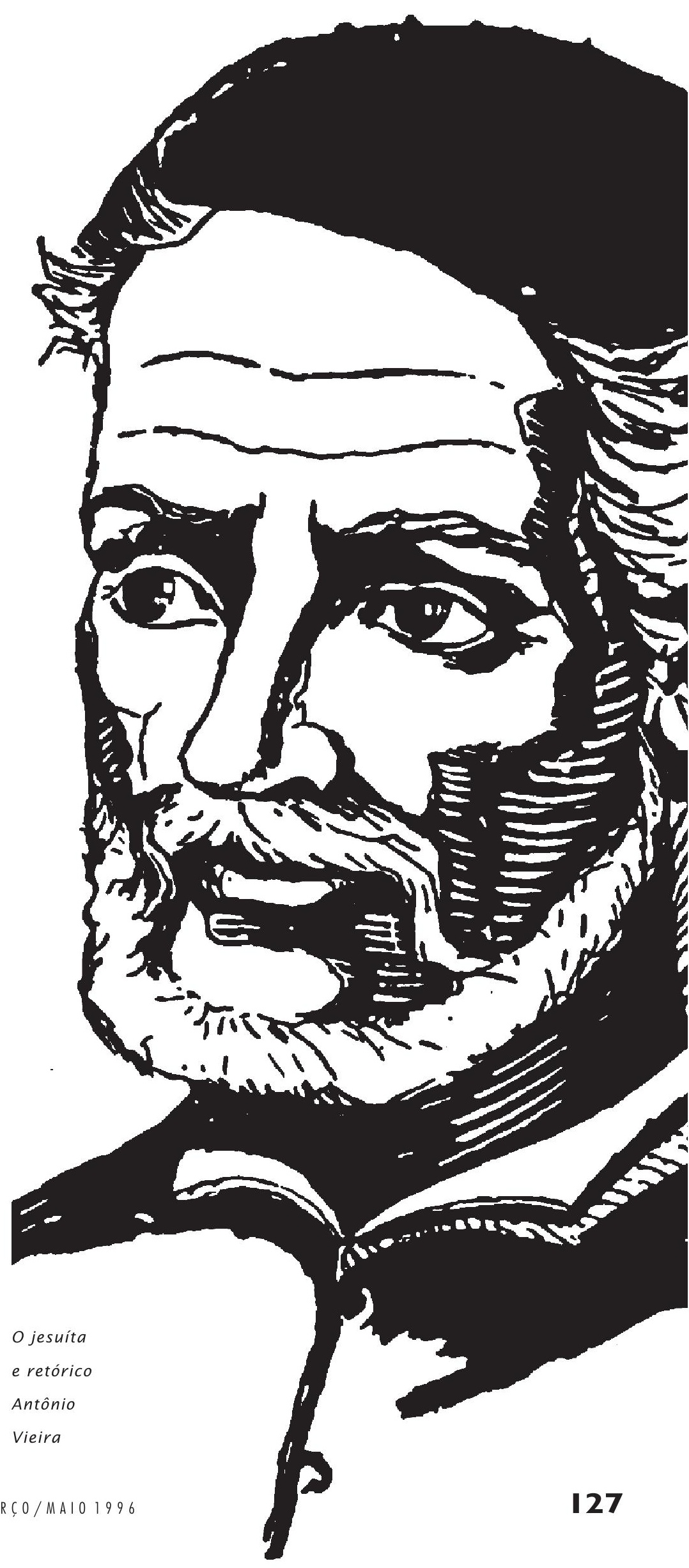


o mundo assistiria à aparição do novo Daniel, Vieira mesmo, quem sabendo ler adequadamente os vaticínios e as marcas do céu, haveria de esclarecer para os portugueses e para o mundo todo a ciência dos porvires.

Mas 1666 chegou e nada extraordinário aconteceu. D. João IV não ressuscitou, o Quinto Império continuou sendo um mero assunto livresco, e o Encoberto persistiu na sua ocultação. Ironia da sorte: o presumido desvelador do mistério passaria o ano todo no cárcere, e o mistério se desmancharia na trivialidade do presente. Vieira, doente e preso, havia tentado escrever contra o tempo; o tempo agora voltava para contradizer suas esperanças e assinalar seu excesso. Contudo, Vieira nunca descartaria a hipótese da consumação do Quinto Império, nem a idéia de haver futuras felicidades para Portugal, reino escolhido por Cristo para encabeçar Seu Reino. Racionaria essas hipóteses em obras igualmente inacabadas, como Clavis Prophetarum e Quinto Império. Como diz Azevedo:

"Vieira era um gênio incompleto: nas grandes obras que meditou não correspondeu a capacidade de execução à facilidade da concepção; nenhuma pôde acabar, e alguma nem mesmo foi principiada"(5).

Se da magna História do Futuro ficou o esboço, de Clavis Prophetarum ficaria apenas um resumo, feito em latim por outro jesuíta. Documentos que servem como prova de desengano: desengano do autor, que falhou como anunciador de futuros, desengano político daqueles que como Vieira acreditaram nas glórias futuras de Portugal, desengano nosso, que assistimos em Vieira à impossibilidade de desvendar o futuro. Pois se o futuro deixa avisos no presente, acontece que esses avisos podem ser interpretados de maneira errada, sempre e quando não forem, por defeito da percepção ou por indiferença, simplesmente ignorados. No presente juntam-se as premonições, as suspeitas e os sinais do futuro que vem chegando: lendo Vieira sabemos que de qualquer modo, mesmo decifrando ou não esses avisos, será tarde. No melhor dos casos, ficaria o consolo de haver previsto partes do real (consolo pobre, que adverte que prever o futuro quase nunca significa modificá-lo); no pior dos casos, ficará um esboço, uma coisa imperfeita (como o tempo verbal que utilizamos para enunciá-la: futuro imperfeito, meramente virtual), uma curiosidade. É assim como permanece hoje e dura a História do Futuro.

Fragmentos de uma obra vastíssima por um lado, pelo outro um simulacro. O que hoje chama-se História do Futuro era na verdade o "Livro Ante-primeiro, Prolegômeno a toda a História do Futuro, em que se Declara o Fim e se Provam os Fundamentos dela. Matéria, Verdade e Utilidade da História do Futuro", texto publicado pela primeira vez em 1718, em Lisboa, e escrito por Vieira em 1664. Em relação a este "Livro Ante-primeiro", em abril de 1664 Vieira informava:

"Os alicerces e primeiras paredes vão tôdas fundadas em autoridade divina, e pasmo de ver quão grandes tesouros estão escondidos no que todos trazem entre mãos e diante dos olhos. Já tomara que alguma parte estivera em estado de se apresentar aos de Vossa Senhoria, mas Deus ajudará" (6).

Já em março do ano seguinte estava o texto em mãos do copista. $\mathrm{O}$ manuscrito (ao parecer, contra a vontade de Vieira) seria lido pelo Rei, quem por um decreto mandou que o Provincial assistisse ao autor para que fosse terminada em breve a obra toda, o que, de fato, nunca aconteceria.

Duas menções auto-referenciais encontramos neste "Livro Ante-primeiro". As duas enfatizam seu caráter introdutório. Na primeira Vieira esclarece que a História do Futuro haveria de se dividir em sete partes ou livros:

"No primeiro se mostra que ha de haver no Mundo um Novo Império; no segundo, que Império ha de ser; no terceiro suas grandezas e felicidades; no quarto os meios por que se ha de introduzir; no quinto, em que terra; no sexto, em que tempo; no sétimo, em que pessoa. Estas sete cousas são as que ha de examinar, resolver e provar a nova história, que escrevemos, do Quinto Império do Mundo" (7). 
Dessas sete partes, o "Livro Ante-primeiro" era apenas um prolegômeno, onde se discutiam certos assuntos teóricos relativos à ciência dos porvires: condição de verdade, interpretação, tempos, profecias:

"Também excitaremos a este fim e resolveremos várias questões muito importantes ao conhecimento das prophecias, pela ordem que a dignidade ou occassião o fôr pedindo, e esta será a própria matéria de todo este livro, a que, por isso, chamaremos 'Ante-primeiro', e é como alicerce de todo o edifício; e posto que todo este tão largo prolegómeno, em rigor não seja 'História do Futuro', senão preparação ou apparato para elle" (8).

Ilusões de Vieira, que o tempo derrubaria: como esses prédios que a burocracia ou a negligência deixam incompletos, a História do Futuro acabaria sendo um alicerce sem edifício, um simulacro que, sob o mesmo nome, agora substitui para sempre o que fora planejado como real.

\section{ESPELHO DO PORVIR}

Como a História da Eternidade de Borges, o título desta História do Futuro inclui também um paradoxo. Entendida a História como narração de feitos passados, disciplina voltada para o já acontecido, como pretender historiar o futuro? Escrever a História supõe trabalhar com o rigor das datas, com sucessos que estão inscritos definitivamente no passado; no futuro, no entanto, não há datas, nem nomes, salvo os indicados pelas previsões. Aplicar o rigor da verdade a essas previsões, como se no presente e no passado estivesse já fatalmente estabelecido o que iria acontecer, é o problema lógico que a obra de Vieira tentaria resolver.

No "Livro Ante-primeiro" (que, todo ele, é uma longa justificação), Vieira justifica o título dizendo que o inaudito de sua "nova e nunca ouvida história" exigia também um título inaudito:

"Mas porque não cuide alguma curiosidade crítica que o nome do futuro não concorda nem se ajusta bem com o título de história, saiba que nos pareceu chamar assim a esta nossa escriptura; porque sendo novo e inaudito o argumento della, também lhe era devido o nome novo e não ouvido" (9).

Esse título não fala nem por exagerações nem "por hyperboles nem synedoches" (10). O futuro de que ele fala é aquele que já estava chegando; o tempo, o daquele mesmo século; o mundo, aquele em que os homens viviam: " $\mathrm{O}$ Mundo que Deus creou, o Mundo que o não conheceu e o Mundo que o ha de conhecer"(11).

Para Vieira, não há contradição alguma entre "história" e "futuro". Ambos se complementam, como se complementam "história" e "passado". Se o passado se revela na história, há uma história que pode revelar o futuro, não por aproximações, mas com idêntico método e guiada por idênticas leis:

"E porque havemos de distinguir tempos e annos, signalar províncias e cidades, nomear nações e ainda pessoas, quanto o soffrer a matéria, por isso sem ambição nem injuria de ambos os nomes, chamaremos a esta narrativa história, história do futuro" (12).

"Impossível pintura parece antes dos originaes retratar as copias, mas isto é o que fará o pincel da nossa história" (13). Se a história é pensada como retrato do já acontecido, como reflexo que, narrando, acolhe em um discurso os nomes e os eventos passados, como tecido urdido pela memória, como cópia de um original, como é possível que haja cópias do que não sucedeu? Como poderá haver uma memória anterior (sem deixar de ser memória e não fantasia), como um espelho que reflita os eventos que ainda não foram?

Mas esses reparos não parecem ser pertinentes para alguém que, como Vieira, acreditava que tudo já tinha sido escrito, tudo desenhado previamente pela inteligência divina:

"A história mais antiga começa no princípio do Mundo; a mais estendida e continuada acaba nos tempos em que foi escripta. Esta nossa começa no tempo em
8 Idem, ibidem, p. 157. 9 Idem, ibidem, p. 39. 10 Idem, ibidem, p. 53. 11 Idem, ibidem, p. 54. 12 Idem, ibidem, p. 40. 13 Idem, ibidem, p. 37. 
que se escreve, continua por toda a duração do Mundo e acaba com o fim delle; mede os tempos vindouros antes de virem, conta os sucessos futuros antes de sucederem, e descreve feitos heróicos e famosos antes da fama os publicar e de serem feitos" (14).

Vieira trabalha com a noção cristã do tempo, já estabelecida por Santo Agostinho: tempo linear, tempo como processo teleológico que começa com a Criação e acaba com o Juízo. Tempo que obedece por completo à vontade divina e que, como tal, não pode ser desviado nem alterado. Por isso não é estranho escrever a história do futuro, porque o futuro já aconteceu no plano de Deus, e a história, através das profecias e da Escritura, funciona como memória e espelho desse plano. O plano é anterior aos sucessos que o confirmarão, e os sucessos estão necessariamente determinados por esse plano. Para conhecer os sucessos, trata-se apenas de saber ler o plano, ou seja, de interpretar as marcas deixadas pela divindade. História do futuro, então, para Vieira, não é adivinhação, senão interpretação de fatos e decifração das palavras que os anunciam.

Trata-se do mesmo trabalho intelectual que se precisa para escrever as histórias do passado. "Xenophonte escreveu a dos persas, Herodoto a dos egípcios, Thucydides a dos gregos e Livio a dos romanos": eles, escrevendo e interpretando, testemunharam e confirmaram o passado; Vieira, escrevendo e interpretando, compõe a história que para os homens é futura, mas que para o desígnio divino já é passado, ou, melhor ainda, já pertence a um tempo que inclui todos os tempos, o tempo anterior e imutável da Providência divina. Assim, os historiadores do passado "escreveram histórias do passado para os futuros, nós (afirma Vieira) escrevemos a do futuro para presentes". O tempo, que é ironia, não permitiria que essa história fosse finalmente escrita.

\section{OS HORIZONTES DO TEMPO}

Há uma teoria dos tempos em Vieira, na qual o tempo está embebido de espaços, e o espaço embebido de tempos:
"O tempo, como o Mundo, tem dois hemispherios: um superior e visível, que é o passado, outro inferior e invisível, que é o futuro; no meio de um e outro hemispherio ficam os horizontes do tempo, que são estes instantes do presente que imos vivendo, onde o passado se termina e o futuro começa; desde este ponto tenta seu principio a nossa história" (15).

Por sua vez, esta teoria analisa também os futuros:

"São Paulo, aquelle philosopho do terceiro Céo, desafiando todas as creaturas, e entre ellas os tempos, dividiu o futuro em dois futuros: neque instantia, neque futu$r a$. Um futuro que está longe e outro futuro que está perto; um futuro que ha de vir e outro futuro que já vem, um futuro que muito tempo ha de ser futuro neque futu$r a$; e outro futuro que brevemente ha de ser presente neque instantia. Este segundo futuro é o da minha história” (16).

Sobre a essência dos três tempos, passado (que deixou de ser), presente (que passa e é) e futuro (que não existe ainda), e sobre a essência do tempo - um dos principais temas da metafísica-muitas páginas já foram escritas. Houve certo autor - resenhado por Borges na História da Eternidade (17) - que negava o futuro, por considerá-lo "uma mera construção da nossa esperança", e assim reduzia o atual "à agonia do momento presente se desintegrando no passado". Por outro lado, uma das escolas filosóficas da Índia, segundo Borges, nega o presente, por considerá-lo inapreensível, por "La naranja está por caer de la rama, o ya está en el suelo. Nadie la ve caer" (18). Conhecida também por todos será a doutrina que supõe que o tempo é circular, e que fala de um eterno retorno do mesmo: em algum momento do tempo, alguém dirá as mesmas coisas que está dizendo agora, e que já foram ditas - por ele-em algum momento anterior, e assim ad infinitum.

Esta doutrina das eternas repetições pode representar uma das mais sugestivas conjecturas acerca do tempo; Vieira, porém, se hoje vivesse (ou se voltasse, algum dia), 
refutaria essa teoria com todo seu aparato argumentativo, em infinitos volumes que postulariam e defenderiam a linearidade do tempo. Na concepção cristã, o tempo consta de um passado (que a memória torna visível), um presente (marcado pela atenção) e um futuro (invisível, mas já contido na expectativa). Essas três potências da alma (memória, atenção, expectativa) convivem no conceito agostiniano de intentio: a intentio da alma condensa as três (e os três tempos) num único momento: o presente do presente, o do passado e o do futuro. A intentio corresponde ao que Vieira chama de "horizontes do tempo", "estes instantes do presente que imos vivendo, onde o passado se termina e o futuro começa". É nesse território mutável onde o autor situa sua História do Futuro. Território entendido menos como um instante (o que já passou) que como uma era, era efêmera que existe entre o passado (passado que é basicamente o das verdades da Escritura) e o futuro iminente (onde essas verdades se constatarão): neque instantia, o "futuro que brevemente ha de ser presente".

Vieira escrevia a História do Futuro sabendo que a iminência desse futuro a tornava perecível. A grandiosidade da obra consistiria em haver anunciado o futuro, mas quando esse futuro chegasse, a obra deixaria de ter sentido, ou em todo caso mudaria de gênero: deixaria de ser profecia, para se transformar em documento. "Só digo que quando assim suceder, perderá esta nossa história gloriosamente o nome e que deixará de ser história do futuro porque o será do presente" (19).

As contingências da sorte, todavia, não lhe permitiriam cumprir esse propósito. Uma hipótese (puramente ficcional) diria que Vieira não terminou de escrever sua obra para que ela não morresse, para que o tempo, mesmo se a confirmasse, não a recluísse na melancólica categoria de documento. Outra hipótese (também ficcional) diria que Vieira se embarcou no projeto de escrever a História para se livrar, como se ela fosse um escudo, da opressão do tempo, criando um eterno presente, o da escrita, onde o passado "allumia" e o futuro está, sempre, por chegar. Praescientiae clypeum: "Que vem a ser esta nossa História do Futuro senão escudo de presciencia? Armados com este escudo, que trabalhos, que perigos nos póde offerecer o mar, a terra e o Mundo, e que golpes nos póde atirar com todas as forças de seu poder, que não sustentemos nelle com animosa constancia?" (20). Um escudo contra o tempo; acaso Vieira acharia absurda essa hipótese. Nós, como leitores, podemos nos entregar a ela.

\section{UM RECURSO CONTRA O DESATINO}

Vieira fala do "desejo insaciável” que os homens sempre tiveram "de saber os futuros" (21). A continuação apresenta os diversos modos que foram usados, e se usam, para os fins da adivinhação, "sciencias, ou ignorancias das artes, ou superstições que os homens inventaram, desde a terra até o Céo, levados deste apetite". Cada um dos quatro elementos tem um modo particular de servir à adivinhação: a "Agromancia, que ensina a adivinhar pelas cousas da terra"; a "Hydromancia, pelas da água; a Aeromancia, pelas do ar, e a Pyromancia, pelas do fogo". Também a "Physionomia nas feições do rosto", "a Chiromancia, nas raias da mão", "a Astrologia judiciária" ou a "triste e funesta Nicromancia que, frequentando os cemitérios e sepulturas no mais escuro e secreto da noite, invoca com deprecações e conjuros as almas dos mortos, para saber os futuros dos vivos" (22). Por outra parte, também foram consultados os sonhos, "as entranhas palpitantes dos animaes", os cantos e vôos das aves, "os números, os nomes e as letras, os dias e os fumos, as sombras e as côres", e até "o ranger da porta, o estalar do vidro, o scintillar da candeia, o topar do pé, o sacudir dos sapatos": "tudo notavam como avisos da Providencia e temiam como presságios do futuro".

Mediante a acumulação (colocando todos os modos dentro da mesma categoria) Vieira ironiza e rejeita de vez o suposto poder desvelador destas artes. Tratam-se, para ele, de meras superstições, causadas pela "cegueira e o desatino". Da "Chiromancia" se burla dizendo que é uma arte "certamente merecedora de ser verdadeira, pois punha a nossa fortuna nas nossas mãos" (23). Na Astrologia, lhe parece absurdo que "uma só hora o

\footnotetext{
19 Antônio Vieira, op. cit., p. 47.

20 Idem, ibidem, p. 94. 21 Idem, ibidem, p. 33. 22 Idem, ibidem, pp. 33-4 23 Idem, ibidem, p. 34.
} 
instante da vida - aquele do nascimento levantam ou figura, ou testemunhos a todos os sucessos della" (24). Acreditar nas revelações das entranhas de um animal lhe é inadmissível, "como se um bruto morto pudesse ensinar a tantos homens vivos" (25).

Vieira refuta o valor de todas essas artes, por serem falsas ou por dependerem todas elas da "contingência da sorte". Condena o método dessas artes, mas não o desejo que as anima. "Tanto foi em todas as idades do Mundo e tanto é hoje na curiosidade humana $o$ appetite de conhecer o futuro" (26). Esse apetite, que Vieira reconhece como natural em todos os homens, é conseqüência da ignorância; porque "o homem, filho do tempo, reparte com o mesmo a sua sciencia ou a sua ignorancia: do presente sabe pouco, do passado menos, e do futuro nada" (27). Essa condição do futuro, a de ser por completo ignorado, aviva o desejo de desvendá-lo: "não buscam os homens os futuros porque os acham, senão que vão sempre após elles, porque os amam" (28). Tão grande é esse desejo, esse "amor", que acaba por multiplicar - levando-as ao absurdo - as formas de vaticinar. Vieira compartilha esse desejo, constrói a partir desse desejo seu método e sua argumentação, e o sacia numa fonte que não admite erros, por ser verdadeira e por ser revelada: a Escritura.

Contudo, parece haver alguma coisa em comum entre essas artes "cegas e desatinadas" e o caminho de Vieira. Ambas as posturas supõem uma determinada maneira de olhar o universo, não pelo que aparenta, mas pelo que poderia sugerir. Ambas supõem que é possível pressentir os desígnios que estão ocultos numa materialidade qualquer. Muda, porém, o mundo fáctico ao qual se dirige esse olhar em procura dos vaticínios: ali é o fogo, o voar das aves ou as almas dos mortos; aqui a Palavra de Deus. Para Vieira o futuro só pode ser lido nas Escrituras; os outros méto- dos não poderão aportar mais do que falácias e enganos, por carecerem, basicamente, do fundamento da verdade.

Pelo contrário, e à falta de uma, Vieira assinala que sua História está sustentada por quatro gêneros de verdade:
"Estes quatro gêneros de verdade são os de que repartidamente se comporá toda a História do Futuro, merecendo, segundo todas as suas partes, o nome de história verdadeira, posto que não em todas com igual grão de certeza. Nas do primeiro gênero, verdadeira com certeza de fé. Nas do segundo, verdadeira com certeza theológica. Nas do terceiro, verdadeira com certeza moral. Nas do quarto, verdadeira com certeza provável, sendo a excellencia singular desta história que toda ella, ou provável, ou moral, ou theológica ou canonicamente, será fundada na primeira e summa verdade, que é o mesmo Deus" (29).

A fé termina assim sendo o recurso contra os desatinos, e a garantia de verdade da História. Fé em Deus e nas Escrituras, sim, mas também apelo ao leitor para que tenha fé no intérprete que, decifrando as páginas escuras e estabelecendo o sentido final das profecias, atende sua Palavra e a revela.

\section{ATÉ QUE AMANHEÇA O DIA: VIDENTES E INTÉRPRETES}

“Temos (diz o príncipe dos Apóstolos) as prophecias e palavras certíssimas dos prophetas, as quaes devemos observar e attender, usando dellas como de candeia luzente em lugar escuro e caliginoso, até que amanheça o dia. Lugar escuro e caliginosoéo futuro; a candeia que allumia são as prophecias, o sol que ha de amanhecer é o cumprimento dellas" (30).

Há, nos diz Vieira, dois tipos de figuras que se encarregam de esclarecer a ciência dos futuros. Ambos trabalham com essa matéria "escura e caliginosa" que é o porvir, e ambos têm um certo tipo de conhecimento sobre ela. Por um lado estão os profetas, cujo saber provém da revelação; assim Daniel, por exemplo, ou Isaías viram os futuros porque eles lhes foram revelados pela Providência. Para os profetas, a adivinhação é um dom divino que neles se personifica, e, quanto mais simples for o profeta-como no caso de Bandarra, 
sapateiro ignorante -, maior a garantia de verdade. São eles os instrumentos, os emissários da vontade superior. Vieira os chama de "videntes":

"Por isso os prophetas na Sagrada Escriptura se chamam por antonomasia 'Videntes': porque com o lume da prophecia entravam nos lugares escuríssimos e secretíssimos dos futuros, e viam nelles claramente aquellas cousas para que todos os outros homens são cegos" (31).

Contudo, as revelações feitas pelos videntes, às vezes, ainda participam de alguma classe de escuridão. Não pelas palavras que as integram (que, como reveladas, são verdadeiras e perfeitas), mas pelo sentido, que a finitude de entendimento dos homens nem sempre consegue captar plenamente.

Mas, por que acontece isso? Por que algumas profecias permanecem sendo tão escuras quanto o futuro que supostamente desvendam? Para responder a esta interrogação, Vieira postula uma idéia interessantíssima: a do suspense divino. Deus "encobre as cousas futuras, ainda quando as manda escrever primeiro pelos prophetas, que nos não deixa comprehender, nem alcançar os segredos de seus intentos, senão quando já tem chegado ou vem chegando os fins delles, para nos ter sempre suspensos na expectação e pendentes da sua providencia" (32). Deus cria o suspense, provoca a expectativa e a curiosidade, e não revela de vez os futuros para fortalecer ainda mais os laços com os homens. Às vezes as profecias são muito claras, mas, mesmo assim, Deus “costuma atravessar entre ellas e os nossos olhos umas certas nuvens, com que sua mesma clareza se nos faz escura" (33).

É condição das profecias serem parcialmente ininteligíveis; são como provas que Deus impõe para aguçar os raciocínios dos homens, e para que os homens não esqueçam que quem manda é sua Vontade. Por isso, além dos profetas, para desvendar a ciência do porvir precisa-se de intérpretes, intérpretes para dissipar essas "certas nuvens" que impedem o total esclarecimento do revelado, intérpretes que - através da inspiração e mediante a "candeia luzente" das profecias - se internam nas sombras até dar com o sentido verdadeiro e completo das palavras anunciadas.

Como intérprete se assume Vieira na História do Futuro. O saber do intérprete não depende da revelação, mas da razão, da sua própria capacidade de encontrar o fio que lhe permita sair com a verdade do labirinto das profecias: "por este modo entraremos também nós pelo escuro e intrincado labiryntho dos futuros. As prophecias e os doutores nos servirão de tochas; o entendimento e o discurso de fio, isto é, quanto às prophecias e prophetas canonicos" (34).

No "Livro Ante-primeiro" Vieira descreve em que consiste seu método de interpretação: 1) escolher entre todas as profecias que pertençam (clara ou presumidamente) ao tempo a ser revelado; 2) ajuntar as escolhidas, ordená-las e "tirar a luz para beneficio público” (35). Ordená-las significa construir um discurso, explicá-las com outras palavras que situarão adequadamente essas profecias no tempo e no espaço aos quais se referiam. A partir das profecias da Escritura, o discurso argumentativo será "o architecto de toda esta grande fábrica, dispondo, ordenando, ajustando, combinando, inferindo e acrescentando tudo aquillo que por consequencia a razão natural se segue e infere de nossos princípios" (36). Interpretação é trabalho de engenharia, que "dilata e fructifica" as profecias. É um trabalho hermenêutico que supõe um certo exercício de tradução, baseada numa explicação argumentada e numa justificativa dessa explicação. A matéria das profecias é a palavra revelada; a da interpretação é a lógica e a dedução.

"De sorte que ajuntando o lume natural do discurso ao lume sobrenatural da prophecia, com o cuidado, estudo e industria própria, lendo, disputando e meditando, vinham a estender e a adiantar muito as mesmas prophecias" (37).

Esforço solitário, realizado entre livros e num espaço fechado, a interpretação em Vieira é o emblema de toda escrita: trabalho intelectual, obstinado e, às vezes, finamente inútil.
31 Idem, ibidem

32 Idem, ibidem, p. 172 33 Idem, ibidem, p. 173 34 Idem, ibidem, p. 155 35 Idem, ibidem, p. 77. 36 Idem, ibidem, p. 150 37 Idem, ibidem, p. 152 


\section{GIGANTES E PIGMEUS}

Todavia, nesse trabalho de interpretar, Vieira não é o primeiro. Vieira lê as profecias, mas também as interpretações sucessivas que essas profecias foram suscitando ao longo dos tempos. Aqui Vieira introduz a noção de novidade, que justifica sua própria tarefa:

"Pigmeus nos conhecemos em comparação daquelles gigantes que olharam antes de nós para as mesmas Escripturas; elles sem nós virão muito mais do que nós podemos vêr sem elles; mas nós, como vivemos depois delles e sobre elles por beneficio do tempo, vemos hoje o que elles viram e um pouco mais" (38).

Por benefício do tempo: Vieira postula que existe um tempo para poder interpretar fielmente cada profecia. Há, no mundo, condições históricas que permitem desfazer a escuridão das profecias; sem o auxílio dessas condições, o sentido permanecerá necessariamente oculto: "as prophecias se vão descobrindo e entendendo, ordenada e sucessivamente, aos mesmos passos, ou mais vagarosos, ou mais apressados, com que se vão seguindo e variando os tempos" (39).

Há um tempo (futuro) que a profecia esclarece, mas a medida da profecia é o tempo (presente) no qual ela pode ser interpretada. Por isso Vieira sabe "um pouco mais" que os intérpretes anteriores: porque houve uma história que se desenvolveu entre eles e Vieira durante os séculos que os separam, e porque ele próprio é aliado do presente. Se há uma memória que recorre aos intérpretes antigos, há também um entendimento (presente) que dilata e completa as leituras anteriores das profecias. Esse "pouco mais", essa diferença é o que resta entre a memória do passado e o saber do presente.

Vieira expõe três razões para legitimar uma nova (a sua) leitura das profecias: "As razões que nos movem e obrigam são três. A primeira, porque os doutores antigos não disseram tudo. Segunda, porque não acertaram em tudo. Terceira, porque não concordaram em tudo" (40). A nova leitura de Vieira anula essas divergências e im- prime o sentido verdadeiro ao texto.

Dois fatores permitem que a leitura de Vieira seja mais arguta que as anteriores interpretações. O primeiro refere-se ao método: os intérpretes antigos leram as profecias buscando seus sentidos alegóricos e místicos e deixando de lado os literais. Vieira, pelo contrário, lê o que ele chama "sentido genuíno e literal do texto":

"Os padres antigos, que buscavam só nas Escripturas a Christo, e nesta preciosíssima margarita empregavam todo o cabedal do seu estudo; os modernos, que se não determinam no thesouro das Escripturas a um só genero de riquezas, acham, além da mesma margarita, muitas outras pedras, também preciosas, e tiram daquelle thesouro (como dizia Christo) nova et vetera, riquezas novas $\mathrm{e}$ velhas: as velhas, que são as notizias das verdades já passadas; as novas, que são o conhecimento das outras futuras" (41).

Esse "os modernos" deve ser entendido como uma modesta alusão a si próprio. As "novas riquezas" são as palavras em si mesmas, estudadas nos seus aspectos etimológicos e até fonológicos. Seguindo esse método, Vieira interpreta uma das profecias de Isaías $(18,1)$ como destinada aos povos maranhenses, usando curiosos argumentos que, às vezes, até recorrem à própria língua indígena para se confirmar. Assim, "in vasis papiri" de Isaías significaria, para Vieira, as canoas, as "igara" dos "iguarunas". Os cimbalo alarum seriam "maracás" e, ao mesmo tempo, "maracatim", nome com que os indígenas designavam os navios europeus. E, assim por diante, cada uma das palavras de Isaías é aplicada (alguns dirão: não sem cometer alguma falácia ou arbitrariedade) à realidade maranhense que o remoto profeta já havia entrevisto numa profecia que, agora, era esclarecida, com o auxílio da novidade e à luz de novos fatos, por Vieira.

$\mathrm{O}$ segundo dos fatores que distingue as interpretações de Vieira das anteriores é justamente esse: o surgimento de novos parâmetros históricos e geográficos que, com sua aparição, outorgam um novo sentido às 
profecias, e obrigam a lê-las de outra maneira. Na época dos primeiros intérpretes, não havia no mundo "verdadeira e exacta cosmographia". O mundo ignorava a existência da América; como, então, os intérpretes iam dar com o significado verdadeiro de uma profecia referida à América, se desconheciam por completo a existência desse continente? As profecias falavam de uma nação que encabeçaria o reino de Cristo, e de um rei dessa nação que iria presidir os destinos do Quinto Império, o da paz e da felicidade, o último antes da chegada do Anticristo: como os intérpretes iam saber que essa nação era Portugal, se não existia nação alguma com esse nome naquela época?

Para Vieira, a história desvia e completa o sentido. A interpretação depende das palavras originais dos profetas, mas depende também, para ser verdadeira, da história. E, quando falamos de "história" em Vieira, falamos, é claro, de uma história já interpretada, uma história que, como tal, está sempre a favor dos interesses do intérprete. Conforme esses interesses, Portugal está sempre acima de tudo; Vieira dedica grande parte do "Livro Ante-primeiro" a convencer a Espanha a aceitar a independência portuguesa (Portugal tinha passado sessenta anos, de 1580 a 1640 , sob o domínio da coroa espanhola), pois essa independência obedecia a um desígnio divino. A História do Futuro estaria dedicada a explicar que também era desejo divino que Portugal comandasse o Quinto Império. Lendo Vieira, parece-nos que história e profecia estão feitas do mesmo material; ambas podem ser interpretadas à vontade, e podem (em aparência) adotarcom docilidade o direcionamento que o intérprete lhe quiser dar. Mas também ambas - profecia e história - se reservam o direito de dar, por sobre as ilusões dos intérpretes, sempre a última palavra.

\section{DIVINAS PROMESSAS}

Vieira apresenta, no "Livro Ante-primeiro", sua história sob o signo da novidade. É o recurso retórico que Curtius (analisando os topoi) denominou "trago coisas inéditas". Vieira deu um sentido diferente a esse topos; se tudo já está de alguma forma contido nas
Escrituras, não existe possibilidade de haver alguma coisa nova - a menos que haja esquecimento, ou ignorância.

Falando da sua obra, Vieira deixa claro que: "Serão novas neste nosso livro cousas que foram primeiro que as que hoje se tem por antigas" (42). A seguir reivindica o caráter inédito dessa obra, não porque ela traga um conhecimento novo (que, de fato, traz), mas porque, para os homens, a novidade surge das deficiências do conhecimento:

"Umas cousas faz novas o esquecimento, porque se não lembram; outras a escuridade, porque se não vêm; outras a ignorância, porque se não sabem; outras a distância, porque se não alcançam; outras a negligência, porque se não buscam; e de todas estas novidades sem novidades haverá muito nesta nossa história" (43).

Esquecimento, ignorância, negligência são, entre outras, as portas pelas quais entra a novidade. Novidade que se propõe como elemento unificador entre o conhecimento eterno (baseado na Escritura, sempre o mesmo e um) e a recepção desse saber. No processo de recepção - por esquecimento ou negligência - muitos conhecimentos verdadeiros se perdem ou, se escurecendo no caminho, não chegam a seu destino. A função da novidade seria recuperar essas perdas e unificá-las, através do discurso revelador do intérprete, na superfície do conhecimento primeiro.

E então Vieira, o porta-voz da novidade, o decifrador de sonhos:

"Os futuros portentosos do Mundo e Portugal, de que ha de tratar a nossa história, muitos annos ha que estão sonhados como os do Pharaó e escriptos como o de Balthasar; mas não houve até agora nem Joseph que interpretasse os sonhos, nem Daniel que construísse as escripturas; é isto o que eu começo a fazer" (44).

No passado, Deus ideou Seu sonho; a novidade consiste em trazer esse sonho para o presente, para divulgá-lo. Nesse propósito de divulgação do sonho divino, Vieira centrou todas as suas esperanças, e é nesse propósito
42 Idem, ibidem, p. 194. 43 Idem, ibidem, p. 195 44 Idem, ibidem, p. 60. 
também que está contida a medida de seu excesso. Se a História do Futuro significa certamente um desvio (excessus) em relação ao resto da produção textual jesuítica, é momento agora de nos ocupar - não para condená-lo (nenhuma autoridade nos assistiria) senão simplesmente para mostrá-lo e documentá-lo-do papel excessivo que Vieira se outorgou a si mesmo escrevendo a História (45).

Esse excesso tem a ver com a verdade que seu autor atribuía à obra, e com a colocação, no curso da história da humanidade que Vieira imaginava ela iria ter. Quanto à verdade, o raciocínio de Vieira é o seguinte: as Escrituras são necessariamente verdadeiras; minha interpretação, posto que atende ao sentido literal e genuíno do Texto (e está "formada e como tecida" das mesmas sentenças dessa Escritura), deve ser, conseqüentemente, verdadeira. A possibilidade de erro na interpretação nunca é admitida por Vieira; nisso consiste sua grandeza, e também sua desmesura:

"Daqui inferimos, sem injuria nem aggravo de quantas histórias até hoje estão escriptas no Mundo, que esta História do Futuro é mais certa e mais verdadeira que todas ellas (excepto sòmente as histórias sagradas" (46).

Por outro lado, a obra é chamada de "livro santo": "sem atrevimento ou demasiada confiança podemos chamar a esta nossa História do Futuro, livro santo" (47), remédio com que todos os homens, e os portugueses em particular, contariam para combater todos os desesperos, todas as infelicidades deste mundo:

45 Ver: Thomas Cohen, "Millenarian Themes in the Writings of António Vieira", in Luso-Brazilian Review, vol. XVIII, no 1, 1991, pp. 23-46. "The argument of the 'Livro Ante-primeiro' is rooted in the expulsion from rooted in the expulsion from Inquisition is attacks on Inquisition is attacks on
Vieira and on the Society as a whole" (p. 31).

46 Antônio Vieira, op. cit., p 159.

47 Idem, ibidem, p. 72.

48 Idem, ibidem.

49 J. L. de Azevedo, op. cit., v 2, p. 28.
"Para esta occasião, e tão apertada, sahe a luz e se offerece ao Mundo este livro santo, no qual acharão os afflictos allivio, os tristes consolação, os atribulados remedio, os combatidos socorro, os desconfiados esperança, paciencia, constancia e fortaleza, tudo por meio da lição e fé das divinas promessas" (48).

Contrariando os desejos do autor (e também os nossos), não houve nem livro santo nem livro algum, e os tristes, os atribulados e os desconfiados devem buscar consolo, mais uma vez, em outro tipo de promessa.

\section{6: AS MARCAS DO CÉU}

1666 é um ano que assinala o limite que o tempo dera a Vieira para confirmar a verdade das profecias. Prazo máximo da esperança, data fatal na qual finalmente o profetizado, mudando de condição, deixaria de pertencer ao difuso espectro dos vaticínios para se transformar em História.

Sonhos milenaristas e medos apocalípticos, hoje, no final deste segundo milênio, parecem aos céticos uma curiosidade, e aos crentes um anacronismo; mesmo esperando que alguma coisa aconteça, e mesmo mantendo a suspeita de que alguma coisa irá acontecer, o espírito da época nos impede de acreditar de vez nessas possibilidades. Muitos podem crer ainda hoje nas grandes mutações do mundo; essas expectativas, porém, parecem estar sempre permeadas de algum receio. Todavia, seria bom lembrarque no século de Vieira, o milenarismo e os pressentimentos apocalípticos faziam parte da corrente do pensar, e eram considerados, com diferença de grau, como fatos que o futuro iria corroborar. As opiniões de Vieira podem nos parecer insensatas, mas, como assinala Azevedo:

"o período em que vivia o jesuíta era agitado por um marulhar de aparições vagas, em que as almas incertas do porvir buscavam seu rumo. Não as podia satisfazer a ciência incompleta, a filosofia incoerente, a religião em debates que o tempo lhes oferecia. Cada um forcejava por descobrir a seu modo o segredo, que sempre atraiu o homem, da direção do mundo e da finalidade da vida" (49).

Mesmo constituindo Vieira, como já dissemos, um excesso, isso não implica de modo algum que fosse um "marginal" dentro do campo das idéias. Para Azevedo, Vieira exprimia "a psique da sociedade convulsa da sua época":

"Desde o Oriente, onde entre as nações que o Turco oprimia o judaísmo chamava 
o seu redentor, à Inglaterra, no outro extremo, dilacerada por contendas sangrentas de religião e governo, a mesma aspiração de tranqüilidade e equilíbrio social incitava os homens a buscarem a chave das possíveis transformações do mundo nos arcanos do céu, ou de celeste procedência, que o esforço dos sábios conseguira desvendar. Assim, segundo as terras e as pessoas, a cabala, a astrologia, a mística rompiam o mistério dos acontecimentos, e davam refrigério aos espíritos, na inquietação perene do futuro" (50).

As meditações de Vieira então não têm nada de extemporâneas. As aspirações lusocêntricas que elas postulam participam, de forma difusa ou pontual (e significam uma revisão), dos ciclos legendários de Portugal (o de Alfonso Henriques, o de João Prestes, o de Sebastião) e das idéias defendidas pelos sebastianistas acerca da existência de um rei Encoberto (D. Sebastião I) que não estaria morto, mas "trasladado", oculto "pela ilusão da morte", e que voltaria para conduzir os destinos de grandeza de Portugal.

1666 parecia ser o ano marcado para o retorno do Encoberto. Vieira, que inicialmente não acreditara nas hipóteses sebastianistas, já a partir da leitura das Trovas de Bandarra tinha passado a confiar firmemente na instauração de um Quinto Império presidido pelo Encoberto português. Nessa confiança baseou todo seu aparato argumentativo. Para ele, não era D. Sebastião (morto na África em 1578; seu corpo nunca foi achado, o que alimentaria a ilusão de que estava escondido e não falecido) o "desejado", o "encoberto" de quem as profecias falavam, senão D. João IV, que fora seu amigo e protetor, e morrera em 1657 , enquanto Vieira encontrava-se no Maranhão.

Ressuscitando, o Rei lusitano venceria os turcos e todos os inimigos de Deus, e decretaria, como imperador de todo o mundo, a paz universal, inaugurando assim o reino de Cristo na terra (51). Esse reino (que, segundo algumas profecias, como a de PseudoMetódio, ia ser efêmero - profecias, é claro, que Vieira deixa de lado para poder armar suas próprias interpretações) duraria, na opinião de Vieira, mil anos (52). Após esse período o Anticristo liberaria "os povos imundos" do encerro ao qual o Encoberto os tinha confinado durante todo o Quinto Império. Antes dessa chegada do Anticristo, o rei iria a Jerusalém e, no monte Gólgota, penduraria a coroa real na Santa Cruz. Cruz e coroa se levantariam ao céu, o rei entregaria a alma a Deus e seria esse o ato final da história humana. Depois seria a hora da luta decisiva entre Deus e as forças diabólicas, e finalmente chegaria o Juízo Final.

Inúmeros avisos certificavam que o ano da reaparição do Encoberto, quando, vencidos os primeiros inimigos da fé, inaugurarse-ia o Quinto Império, seria o de 1666. Mencionaremos aqui apenas alguns desses avisos, que giram em torno do número seis:

a) Certas especulações julgavam que havia firme paralelismo entre os seis dias da Criação (Gen. 2, 2) e as palavras de São Pedro "Um dia, diante do Senhor, é como mil anos, e mil anos como um dia" ("2 carta de São Pedro" 3, 8). Daí se segue que o mundo durará seis milênios (o engenho dos intérpretes sempre conseguia alongar o prazo para poder dizer que esse em que viviam era "o último milênio". Vieira, por exemplo, no "Livro Ante-primeiro" diz que a tradição dos seis mil anos "ainda tem lugar de poder ser verdadeira”, e na segunda Representação, que ao mundo restam 340 anos, embora depois, afirmando que o Reino consumado de Cristo na terra ocupa o sétimo milênio, fale em 1.340 anos) (53).

b) No Apocalipse, 666 é o número da Besta. O número apocalíptico possuía sentido místico para os cabalistas, significando a renovação do mundo.

c) Bandarra, nas Trovas, já tinha apontado o número como indicador de grandes sucessos. Copla C: "Enestes seis/vereis cousas de espantar”. Copla CXXVIII: “Aqueles que aos seis chegarem/ Terão quanto desejarem/ E um só Deus será conhecido" (54).

d) No número 1666, como nos adverte Vieira, "todos os números do abecedário latino se enchem completamente na conta dêste ano, sem acrescentar, nem diminuir, nem trocar ou alterar a ordem dêles: porque o $\mathrm{M}$ vale mil, o D quinhentos, o $\mathrm{C}$ cento, e $\mathrm{L}$
50 Idem, ibidem, p. 36.

51 Para maiores dados, ver: J. Besselaar, "A Profecia Apocalíptica de PseudoMetódio", in Luso-Brazilian Review, vol. XVIII, № 1 , 1991, pp. 5-22.

52 Curtius, em Literatura Européia e Idade Média Latina, assinala que há um na, assinala que há um "transferência"-que é fundamental para a teoria medieval da história. Assim, a passagem do Quarto (o romano) para o Quinto Império seria entendida como renovac̃ão endida como renovação e transdo pode provocada pelos pecados do império declinante. Ver na Bíblia, Eclesiastes 10, 8: "Um reino é transferido duma nação à outra por causa dasinjustiças, edas viusa dasinustiças, e das e de diferentes enganos".

53 J. Besselaar, op. cit., p. 18 54 J. L. de Azevedo, op. cit., v. 2, p. 24. 
cinqüenta, o X dez, o V cinco, o I um; e todos juntos pela mesma ordem fazem 1666: MDCLXVI" (55). Este perspicaz argumento, que visava a demonstrar a excepcionalidade do ano em questão, foi exposto por Vieira na sua defesa perante o Santo Ofício.

e) Entre as notas de Vieira constava que as letras do nome de Mahomet correspondem ao número 666 (56).

f) Um cometa, em fins de 1664 , tinha sido visto em Portugal. Vieira aponta que "o cometa de 1577 , a que se atribui a perda de El-Rei D. Sebastião, segundo a conta de Vossa Senhoria, saiu ou apareceu no mesmo dia que este, e não falta quem ache grandes mistérios nesta correspondência, que verdadeiramente é notável" (57).

g) Outros prodígios, não menos notáveis, também foram destacados por Vieira como prova da proximidade de grandes transformações:

"Em Guimarães vomitou um homem enfermo um dragão com duas asas, de cumprimento quási de um côvado, da cabeça até o meio largo de dois dedos, vermelho e escuro, do meio para a cauda mais delgado e de côr parda. De Roma se escreve houve três dias de nêvoas tão espessas e escuras, que se não viam os homens nem os edifícios, e que as trevas eram palpáveis, como as do Egipto. Tudo são sinais e prodígios que solenizam as vêsperas do ano fatal, por cujas maravilhas nenhum há já tão incrédulo que não espere" (58).

Por outro lado, em Torres Vedras, uma imagem da Virgem tinha suado sangue: "Com o que - dizia Vieira, ainda em 1664 o céu e a terra parece começam a solenizar as vêsperas e expectação do ano de 66" (59).

Todavia, nada fora do comum aconteceria em 1666. Vieira passou o ano inteiro no cárcere, do qual sairia só em 1667. Ainda assim, sempre manteve a certeza de que

55 Idem, ibidem, p. 25 56 Idem, ibidem. 57 Idem, ibidem, p. 35. 58 Idem, ibidem. 59 Idem, ibidem. era desígnio divino que Portugal dirigisse, algum dia, os destinos da humanidade. Também não perdeu as esperanças de que o Encoberto retornaria; desprezando ressuscitar D. João IV (como desprezou, sem dúvi-

da contra seus próprios desejos), o Encoberto de Vieira passaria a ser D. Affonso VI, e depois D. Pedro II, e finalmente os filhos deste, o primeiro morto na infância, o segundo, D. João V. Desta forma obedecia à lógica das suas interpretações primeiras; infelizmente, nenhum dos reis assinalados por Vieira tornou-se imperador do Quinto Império, e por sua vez foram morrendo, sem poder ter a menor certeza (atrever-me-ia a dizer) de que chegariam a ressuscitar, algum dia.

Ainda em 1695 - Vieira tinha 87 anos foi visto nos céus da Bahia outro cometa. Vieira sempre crera que, além dos profetas, os cometas eram o instrumento pelo qual Deus fazia saber ao mundo Sua vontade. Era este cometa em forma de espada, e como tal anunciava golpes, golpes que o infatigável intérprete se encarregou de analisar no "Voz de Deus ao mundo, a Portugal e à Baía", espécie de tratado astrológico escrito por inspiração do fenômeno. Nesse ensaio, Vieira adverte que o cometa podia significar para o mundo grandes calamidades: fomes, inundações, tempestades, pestes, guerras. Tais castigos só podiam ser afastados pela graça da oração e pela penitência...

Como em oportunidades anteriores, desta vez também as marcas do céu não permitiram que seu sentido - se é que tinham algum - fosse desvelado. Infinitas vezes Vieira procurou no céu o mapa que o guiasse para andar pela terra. Lendo esses mapas, ou os inventando, outras tantas vezes se equivocou; até seus últimos dias redigiu os Sermões, no entanto ditava a Clavis Prophetarum, que não conseguiria terminar. Terá entrevisto, finalmente, que há marcas no céu, como na natureza, que parecem estar a ponto de se compreender e nunca se compreendem?

Se foi assim, não haverá sido o único a ter esse pressentimento. No dia da sua morte (17 de junho de 1697) uma estrela nova (dizem) brilhou sobre o Colégio da Baía; o orador das exéquias e muitos presentes confirmaram a versão. No relatório do Reitor, porém, o fato não figura. Verdade ou fábula, tanto faz: acaso as marcas do céu se importam com as interpretações dos homens? 